\title{
Organ crushing tackle: pancreatic, bowel and splenic artery injury from blunt abdominal trauma playing rugby union
}

\author{
Timothy Moore
}

NSW Health, Manly, New South Wales, Australia

\section{Correspondence to} Timothy Moore,

timothy_moore2@hotmail.com

Accepted 6 January 2016
CrossMark

\footnotetext{
To cite: Moore T. BMJ Case Rep Published online:

[please include Day Month

Year] doi:10.1136/bcr-2015-

214124
}

\section{DESCRIPTION}

A 22-year-old man was brought to a small District General Hospital Emergency Department by a relative. The patient had left upper quadrant (LUQ) abdominal pain and vomiting after being the recipient of blunt trauma in the form of a heavy tackle, while playing rugby union.

Initial observations were satisfactory although the patient looked unwell, uncomfortable and nauseous. There was tenderness with guarding in the LUQ and epigastrium.

Blood was confirmed at splenorenal angle on bedside focused assessment sonography in trauma (FAST) scan. The patient was moved to the resuscitation area. Two large bore cannulas were inserted, and he was treated with opiate analgaesia, antiemetics and delayed fluid resuscitation.

The following CT images show intra-abdominal blood with evidence of active bleeding (figure 1). The area of bleeding is shown to transect the pancreas (figure 2). There is also a small and potentially misleading splenic laceration (figure 3). The observation chart shows a clear deterioration correlating to worsening haemorrhagic shock over 3 hours (figure 4). As the patient became tachycardic and hypotensive, packed red cells were transfused.

The patient was transferred by urgent ambulance to the nearest trauma centre, where he was taken to the operating theatre. Laparotomy found transection of the pancreas at mid-body, active bleeding from splenic artery and a large retroperitoneal

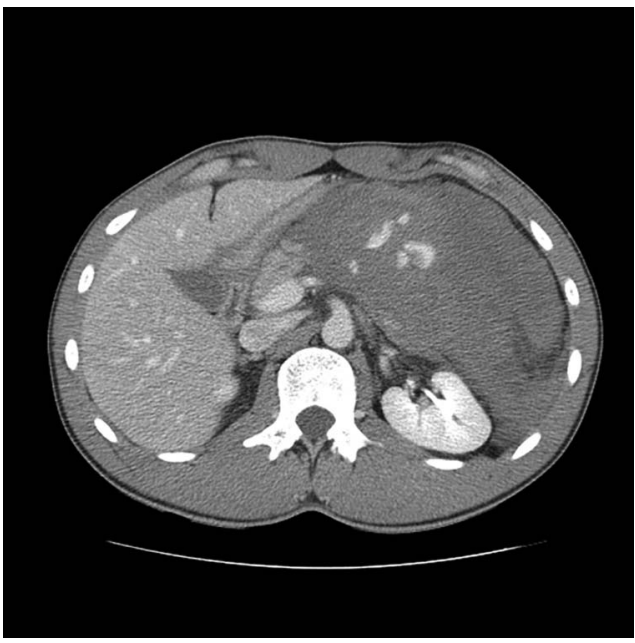

Figure 1 Blush of contrast into area of intra-abdominal blood indicating active bleeding.

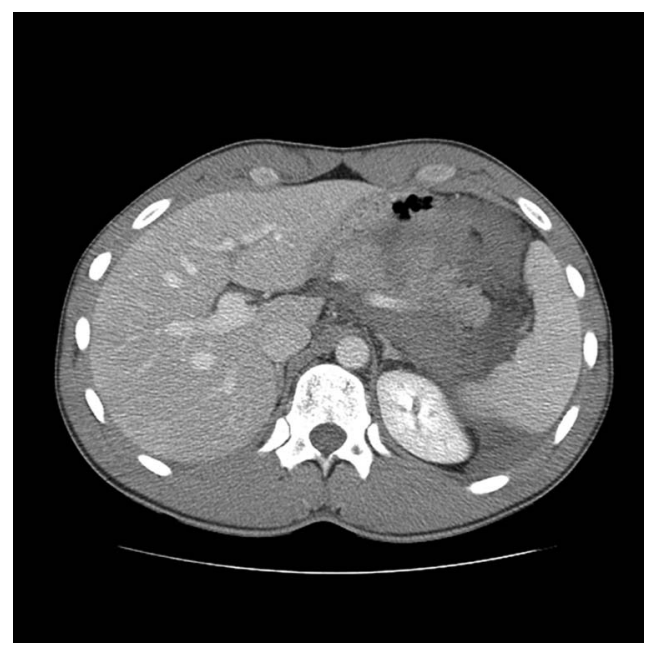

Figure 2 Area of intra-abdominal bleeding is shown to transect the pancreas indicating pancreatic injury has been sustained.

haematoma extending into transverse colon mesentery, leaving an area of non-viable large bowel. Splenectomy, distal pancreatectomy and left hemicolectomy were performed. The patient returned to theatre 2 days later for colonic anastomosis. Haemoglobin fell as low as 78 on day 3. Amylase peaked at 240 on day 1 .

The patient was discharged after 9 days as an inpatient and is now making an excellent recovery.

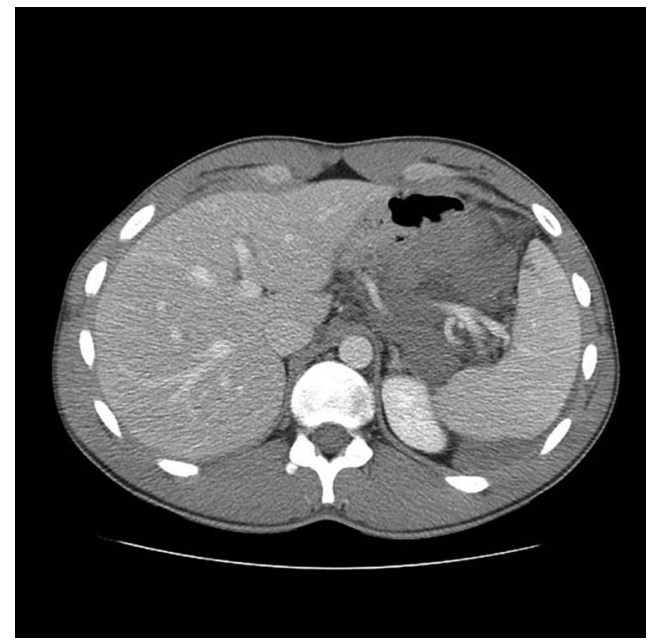

Figure 3 A small splenic laceration can be seen that is unlikely to be the cause of such significant haemorrhage. 


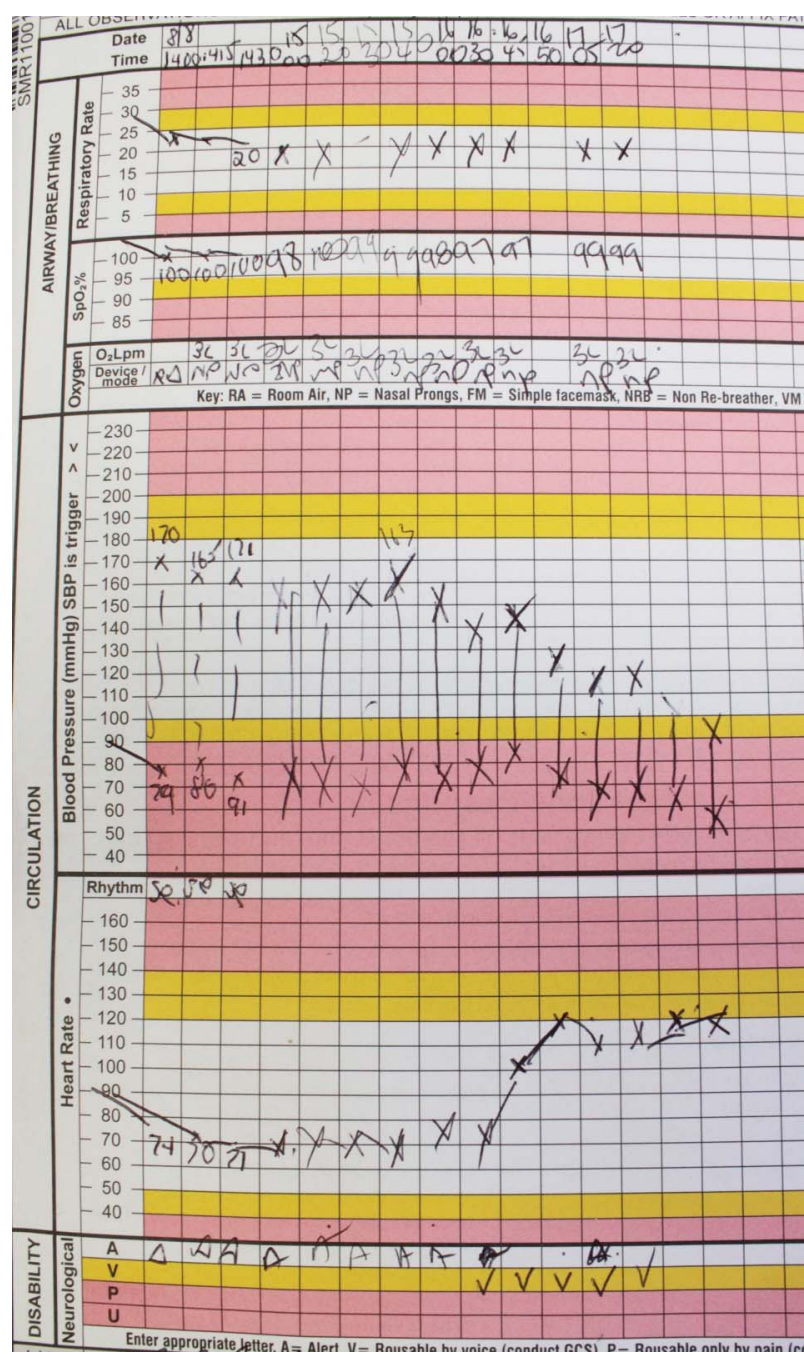

Figure 4 Patient's observations chart over several hours showing worsening haemorrhagic shock including tachycardia, hypotension and decreased conscious level, indicating conservative management is not an option.

\section{Learning points}

- High suspicion of serious injury is key to ensuring early diagnosis of potentially life-threatening injuries in blunt abdominal trauma. Do not be falsely reassured by normal initial observations especially in young, fit patients who have a large scope to compensate.

- Permissive hypotension is controversial but has been shown to have improved outcome in patients with penetrating torso trauma. ${ }^{1}$ Further research is required for blunt trauma. Use of blood products is indicated in resuscitation of haemorrhagic shock classes III and IV. ${ }^{2}$

- Pancreatic injury from blunt trauma is rare. A recent prospective study found $2.5 \%$ of patients who sustained blunt abdominal trauma had evidence of pancreatic injury on CT. Contrast-enhanced multidetector CT correctly identified pancreatic injury in $92 \%$ of cases, making it an excellent resource. $^{3}$

- Transfer of patients to a hospital with the required resources to definitively manage a patient with acute life-threatening trauma should not be delayed. Delay in definitive management can be lethal. ${ }^{2}$

Acknowledgements The authors would like to acknowledge Manly Hospital. Competing interests None declared.

Patient consent Obtained.

Provenance and peer review Not commissioned; externally peer reviewed.

\section{REFERENCES}

1 Bickell WH, Wall MJ Jr, Pepe PE, et al. Immediate versus delayed fluid resuscitation for hypotensive patients with penetrating torso injuries. N Engl J Med 1994;331:1105-9.

2 Rotondo MF, Fildes J, Brasel KJ, et al. Advanced trauma life support student course manual. 9th edn. American College of Surgeons, 2012.

3 Panda A, Kumar A, Gamanagatti S, et al. Evaluation of diagnostic utility of multidetector computed tomography and magnetic resonance imaging in blunt pancreatic trauma: a prospective study. Acta Radiol 2015;56:387-96.

Copyright 2016 BMJ Publishing Group. All rights reserved. For permission to reuse any of this content visit http://group.bmj.com/group/rights-licensing/permissions.

BMJ Case Report Fellows may re-use this article for personal use and teaching without any further permission.

Become a Fellow of BMJ Case Reports today and you can:

- Submit as many cases as you like

- Enjoy fast sympathetic peer review and rapid publication of accepted articles

- Access all the published articles

- Re-use any of the published material for personal use and teaching without further permission

For information on Institutional Fellowships contact consortiasales@bmjgroup.com

Visit casereports.bmj.com for more articles like this and to become a Fellow 